\title{
Soil fertility evaluation and spatial distribution of grasslands in Qilian Mountains Nature Reserve of eastern Qinghai- Tibetan Plateau
}

\author{
Qiang Li ${ }^{1}$, Junyin Yang ${ }^{1}$, Wenhao Guan ${ }^{1}$, Zhigang Liu ${ }^{1}$, Guoxing He ${ }^{1}$, Degang Zhang ${ }^{1}$, Xiaoni Liu ${ }^{\text {Corresp. } 1}$ \\ ${ }^{1}$ College of Grassland Science, Gansu Agricultural University/Key Laboratory of Grassland Ecosystem of the Ministry of Education, Lanzhou, China \\ Corresponding Author: Xiaoni Liu \\ Email address: liuxn@gsau.edu.cn
}

The study assessed the overall soil characteristics of grasslands on Qilian Mountains and rated the soil nutrient status with classification standard of the second national soil survey of China. Nemerow index method was used to evaluate the soil fertility of different grassland types. GIS was used to analyze the spatial distribution of the soil nutrients and provided a database for the grassland's ecological protection and restoration. The study graded the soil organic matter (SOM), total N, and available $\mathrm{K}$ at level 2 (high) or above for most regions, available soil-P at level 4 , while the soil bulk density, total porosity and $\mathrm{pH}$ were $0.77-1.32 \mathrm{~g} \mathrm{~cm}^{-3}, 35.36-58.83 \%$ and $7.63-8.54$, respectively. The rank of comprehensive soil fertility index was temperate steppe (TS) >alpine meadow (AM) > alpine steppe (AS) > upland meadow $(U M)>$ alpine desert $(A D)>$ lowland meadow $(L M)>$ temperate desert steppe (TDS)> temperate desert (TD). The areas with high, medium and low soil fertility accounted for $63.19 \%, 34.24 \%$ and $2.57 \%$ of the total grassland area. Soil fertility of different grassland types had different main limiting factors, for instance, the $\mathrm{pH}$, total $\mathrm{N}$ and SOM were the main factors limiting soil fertility in LM, while $\mathrm{pH}$ and available $P$ were the main factors limiting soil fertility in UM, AM, TS and AS. In summary, the grassland soil fertility was generally at the mid-upper level, and the main limiting factors were found in the different types of grasslands and their spatial distributions were figured out. Our findings also indicated that the typical grasslands and meadows may require phosphorus application, while for desert grasslands, both nitrogen and phosphorus were required to improve their comprehensive soil fertility and grassland productivity . 
1 Soil fertility evaluation and spatial distribution of grasslands in Qilian Mountains Nature Reserve of eastern Qinghai-Tibetan Plateau

Qiang Li; Junyin Yang; Wenhao Guan; Zhigang Liu; Guoxing He; Degang Zhang; Xiaoni Liu ${ }^{1}$

\section{Introduction}

Qilian Mountains Natural Reserve is one of the most sensitive regions under global warming and an important ecological security barrier in northwestern China (Wang et al., 2001). Grassland ecosystem is the largest ecological system in Qilian Mountains Natural Reserve, which accounts for $74.3 \%$ of the total area and plays an critical role in maintaining biodiversity, water conservation and ecological balance of the natural reserve (Li et al., 2019). In the last decades, the grassland ecosystem have been severely damaged because of climate change, human activities and mismanagement in this area. Understanding the current status of grassland soil in Qilian Mountains is of great significance to the health and sustainable maintenance of grassland ecosystem. Due to differences in topography, precipitation and temperature, the distribution of same grassland type is very patchy, discontinuous and irregular. Previous studies found that different grassland types have large differences in soil nutrients due to the differences in vegetation types and utilization methods (grazing, water conservation and sand fixation) (Fayiah et al., 2019; Chen et al., 2020).

Soil fertility directly affects the health of grasslands and is also influenced by grassland vegetation (Hao et al., 2020). Without human disturbance, the growth and distribution of grassland vegetation is strongly affected by soil fertility apart from climate (Wang et al., 2016; Harpole et al., 2007). Soil fertility affects not only the growth of grassland vegetation, but also the grassland ecosystem health (Ma et al., 2019). Therefore, better understanding and proper evaluation of soil fertility characteristics are of great significance to restoration of degraded vegetation, and improvement of fragile grassland ecosystem (Su et al., 2019; Jin et al., 2018).

\footnotetext{
${ }^{1}$ Corresponding author. TEL:13809318054

E-mail address: liuxn@gsau.edu.cn (Liu Xiaoni).
} 
Grassland soil fertility plays a key role in supporting grassland ecosystem services (Clanet, 1980; Hu et al., 2018; Qu et al., 2016). Soil organic matter, available nitrogen, available phosphorus, available potassium, soil bulk density and $\mathrm{pH}$ are the important components of soil fertility, while their contents directly affect grassland vegetation productivity (Wuest, 2015; Li et al., 2014). Many methods have been used for soil fertility evaluation, including Nemerow method (Hua et al., 2018; Shahab et al., 2013), analytic hierarchy process (AHP) (Keshavarzi et al., 2020; Sousa et al., 2012), subordinate function value method, etc. In which, Nemerow index is well recognized and commonly used. This method was developed by N. L. Nemerow and originally was used to evaluate water quality for pollutants (N. L. Nemerow., 1974). It was modified and improved by Chinese scholars (Hua et al., 2018; Shahab et al., 2013; Zhou et al., 2017; Zhou et al., 2018). Nemerow Index is used to evaluate the comprehensive soil fertility, meanwhile the modified Nemerow Index can determine the minimum limiting factor of soil fertility. Nemerow index method can avoid the influence of subjective factors and could highlight the influence of the worst factor of soil attribute factors on soil fertility (Bao et al., 2012). Nemerow comprehensive index method also reflects the limiting factor of plant growth in ecosystem, which can improve the confidence level of the evaluation results (An et al., 2015; Zhou et al., 2017). Comprehensive evaluation of soil fertility combining with geographic information system (GIS) has been widely used to assess spatial distribution characteristics of soil nutrients, which is helpful to explore the relationship between soil nutrients and environmental factors (Wang et al., 2007; Peng et al., 2013; Nie et al., 2016; Brevik et al. 2016; Miller et al. 2016).

Many studies have been carried out on the soil of degraded grassland in Qilian Mountains (Cheng et al., 2019; Wang et al., 2018; Chen et al., 2016). However; there are few studies on grassland soil fertility and its spatial distribution characteristics. Therefore, the aims of this study were to investigate the soil of different grasslands in Qilian Mountains Natural Reserve in order to 1) analyze the distribution characteristics of soil fertility index, and 2) find out the limiting factors of grassland soil fertility to provide scientific insight for improving grassland ecological services.

\section{Materials and methods}

\subsection{Study area}

The study sites were located in the in Qilian Mountains Nature Reserve of eastern Qinghai-Tibetan Plateau, China $\left(94^{\circ} 10^{\prime}-103^{\circ} 04^{\prime} \mathrm{E}, 35^{\circ} 50^{\prime}-39^{\circ} 19^{\prime} \mathrm{N}\right)$. At horizontal direction, there are four vegetation zones in the order of forest, shrub, grassland and desert from southeast to northwest. At vertical direction, , there are three vegetation belts distributed as steppe, forest and alpine meadow from low to high altitude (3000-5564 m). The main types of soil are aridisols, inceptisols and entisols. The precipitation varies from 100 to $500 \mathrm{~mm}$, mostly occurring from June to September. The average annual temperature is approximately $-2.0^{\circ} \mathrm{C}$; the average annual relative humidity is from $20 \%$ to $70 \%$; the annual evaporation is $1200-1400 \mathrm{~mm}$; and the frost-free period is $90-120$ days (http://www. qilianshan. com.cn).

\subsection{Sites selection and sample collection}

This study sites were mainly located on the Qilian mountain natural reserve in Gansu province, China. The grassland types were temperate steppe (TS), alpine meadow (AM), alpine steppe (AS), upland meadow (UM), alpine 
desert (AD), temperate desert steppe (TDS), lowland meadow (LM), temperate desert (TD) (Table 1) (NY/T 29972016, 2016).

The sampling time was from July 23 to August 5, 2019, when the plants were in full bloom. The central points of the typical distribution area of the above 8 types of grasslands (AM, TS, LM, AS, UM, TDS, AD and TD) were selected as the sampling sites (Table 1). A 60-meter sample line was randomly set for each sample site and the sample spots were set for every 20-meter interval. Four soil samples were taken at each sampling site using soil drill (an auger drill) at a depth of 0-30 cm and mixed as one sample. The samples were air-dried and stored in sample bags for further test. Meanwhile, Soil bulk density was measured by a stainless steel cutting ring ( $5 \mathrm{~cm}$ diameter and $5 \mathrm{~cm}$ high) after aboveground biomass was measured, 10 cores at each site.

\subsection{Soil sample measurement methods}

Soil bulk density was determined by core method (Dong et al., 2012). Soil total porosity was determined by water immersion weighing method (Soil Physics Institute, 1978). Soil samples were air-dried at room temperature, and visible roots and other debris in the soil were removed. Each soil sample was sieved through a 2-mm sieve. Soil organic matter was determined by the Walkley-Black method (Nelson and Sommers, 1996). The measurement of total soil N was determined using a micro Kjeldahl digestion procedure (Nelson and Sommers, 1996). Briefly, a small amount of dried soil (passing $0.25 \mathrm{~mm}$ sieves) mixed with $\mathrm{H}_{2} \mathrm{SO}_{4}, \mathrm{CuSO}_{4} \cdot \mathrm{H}_{2} \mathrm{O}$ and $\mathrm{K}_{2} \mathrm{SO}_{4}$, heated and then made up with ammonium-free distilled water. The solution was mixed with $4 \mathrm{ml} \mathrm{40 \%} \mathrm{NaOH}$ and distilled using a Kjeldahl apparatus to release $\mathrm{NH}_{3}$ for the determination of $\mathrm{N}$ content. Available $\mathrm{P}$ was extracted with sodium bicarbonate, and then determined by the molybdenum blue method (Soil Physics Institute, 1978). Available K was extracted with ammonium acetate, and then determined by flame photometry(Soil Physics Institute, 1978).

\subsection{Evaluation of soil fertility}

\subsubsection{Evaluation of individual indicators of soil fertility}

This study used the China second soil census standard (National Geographic Resource Science Sub Center, http://gre.geodata.cn) to rank the grassland soil organic matter, total $\mathrm{N}$, available $\mathrm{P}$, available $\mathrm{K}$, pH, bulk density and total porosity indicators (Table 2) and to compare the differences between different grassland types (Zhou et al., 2017).

\subsubsection{Comprehensive soil fertility evaluation}

Nemerow Index was used to conduct the comprehensive soil fertility evaluation as follows:

$$
F=\sqrt{\frac{F i^{2}+F i m a x^{2}}{2}}
$$

Where $F$ is the Composite pollution index, $F_{i}$ is the average value of each sub-pollution index, $F_{\text {imax }}$ is the minimum value of each sub-pollution index, and $\mathrm{i}$ is the number of the sampling point.

Meanwhile, the improved Nemerow Index was used to determine the minimum limiting factor of soil fertility and it is as follows:

$$
F=\sqrt{\frac{F i^{2}+\text { Fimin }^{2}}{2}} \cdot\left(\frac{n-1}{n}\right)
$$

Where $F$ is the soil comprehensive fertility index, $F_{i}$ is the average value of each sub-fertility index (at one sampling point), $F_{\text {imin }}$ is the minimum value of each sub-fertility index (at one sampling point), and $n$ is the number 
114

115

116

117

118

119

120

121

122

123

124

125

126

127

128

129

130

131

132

133

134

135

136

137

138

139

140

141

142

143

144

145

146

147

148

149

150

of participating indicators.

To improve the Nemerow comprehensive index, the minimum value of $F_{i}$ is used to replace the maximum value of $F_{i}$ in the original Nemerow comprehensive index, which highlights the impact of the soil lowest attribute on soil fertility and can reflect the minimum factor law of plant growth. In addition, the addition of the correction item $\left(\frac{n-1}{n}\right)$ improves the credibility of the evaluation, that is, the more soil sub-fertility index in the evaluation, the greater the value of $\left(\frac{n-1}{n}\right)$ and the higher of credibility. Meanwhile, correction item $\left(\frac{n-1}{n}\right)$ also reflects the difference in evaluation results when the evaluation indicators are not equal.

According to the grading standards of soil properties in China (Table 3), the selected index parameters were standardized to eliminate numerical size differences between selected index parameters. The standardized treatment methods are as follows:

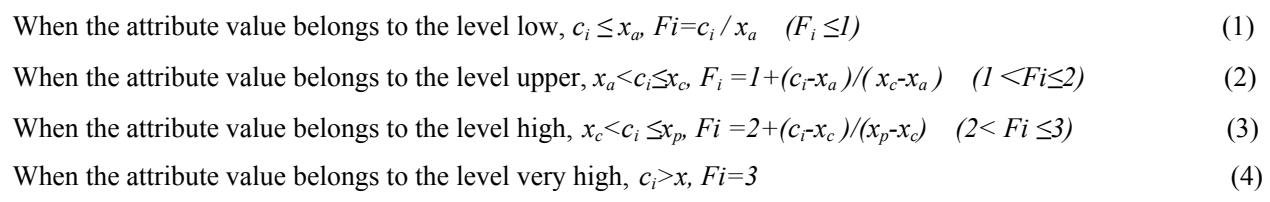

When the attribute value belongs to the level very high, $c_{i}>x, F i=3$

In above formulas, $F_{i}$ is the attribute division coefficient, $c_{i}$ is the measured value of the attribute, and $x_{a}, x_{c}$, and $x_{p}$ are the classification indexes.

The improved Nemerow index method was then used to comprehensively evaluate the grassland soil fertility in Qilian mountain.

\subsection{Soil comprehensive fertility index spatial distribution}

Analysis method based on multiple regression and residues (AMMRR) had been widely used in many studies for grassland spatial interpolation (Liu et al., 2012; Guo et al., 2011). This method is- more accurate than many other interpolating methods and can also effectively avoids systematic errors (Liu et al., 2012; Guo et al., 2011). In this paper, based on the comprehensive fertility index determined by the improved Nemerow index method, the ArcGIS10.2.2 (Nistor, M.M., 2016) used to conduct the spatial analyses including extracting the center points of different grassland types (Fig.1), assigning values for grassland types, performing AMMRR interpolation, and drawing the Qilian mountain grassland soil fertility index spatial distribution. The comprehensive fertility index was divided into low $(<1.50)$, medium (1.50-2.00), and high $(>2.00)$ (Zhou et al., 2017; Zhou et al., 2018).

\subsection{Statistical analyses}

Statistical analyses were conducted using SPSS (version 19.0 SPSS Inc., Chicago, IL, USA). All results were presented as mean and standard deviations. One-way ANOVA and least significant difference (LSD) tests were declared at $\mathrm{P}<0.05$.

\section{Results}

\subsection{Characteristics of grassland soil fertility indexes}

The soil bulk density, total porosity, $\mathrm{pH}$, total $\mathrm{N}$, available $\mathrm{P}$, available $\mathrm{K}$ and soil organic matter were 0.77 $1.32 \mathrm{~g} \mathrm{~cm}^{-3}, 35.36-58.83 \%$, 7.63-8.54, 0.63-4.97 $\mathrm{g} \mathrm{kg}^{-1}, 6.79-24.27 \mathrm{mg} \mathrm{kg}^{-1}, 0.21-1.06 \mathrm{~g} \mathrm{~kg}^{-1}$ and $4.99-131.52 \mathrm{~g} \mathrm{~kg}^{-1}$ respectively (Table 4), and the corresponding Coefficient of variation (CV) of each index was greater than $10 \%$. 
151

152

153

154

155

156

157

158

159

160

161

162

163

164

165

166

167

168

169

170

171

172

173

174

175

176

177

178

179

180

181

182

183

184

185

186

187

\subsection{Soil physical and chemical properties of different grasslands}

The soil fertility indexes for different type grasslands are shown in Table 5 , a significant difference $(\mathrm{P}<0.05)$ was observed between different grassland types. Soil bulk density and total porosity were in a ranking order of desert type $>$ meadow type $>$ steppe type. The $\mathrm{pH}$ was in a ranking order of TD $>$ LM $>$ TDS $>$ UM $>$ AD $>$ AS $>$ $\mathrm{AM}>\mathrm{TS}$. Total $\mathrm{N}$ was in a ranking order of $\mathrm{AM}>\mathrm{TS}>\mathrm{AS}>\mathrm{UM}>\mathrm{AD}>\mathrm{TDS}>\mathrm{LM}>\mathrm{TD}$. The soil organic matter was in a ranking order of TS $>\mathrm{AM}>\mathrm{AS}>\mathrm{UM}>\mathrm{AD}>\mathrm{TDS}>\mathrm{LM}>\mathrm{TD}$. The available $\mathrm{P}$ was in a ranking order of $\mathrm{LM}>\mathrm{TS}>\mathrm{AM}>\mathrm{AS}>\mathrm{UM}>\mathrm{TD}>\mathrm{TDS}>\mathrm{AD}$. The available $\mathrm{K}$ was in a ranking of $\mathrm{LM}>\mathrm{UM}>\mathrm{AS}>\mathrm{TD}$ $>\mathrm{TS}>\mathrm{AM}>\mathrm{AD}>\mathrm{TDS}$.

\subsection{Soil physical and chemical spatial distribution}

The soil physical and chemical spatial distributions were shown in Fig. 2. For most sampling areas, the soil bulk density was $0.75-0.94 \mathrm{~g} \mathrm{~cm}^{-3}$, the total porosity was $50-60 \%$, the $\mathrm{pH}$ values were $8-9$, the SOM contents were 30-134 $\mathrm{g} \mathrm{kg}^{-1}$, the total $\mathrm{N}$ contents were 2.0-5.0 $\mathrm{g} \mathrm{kg}^{-1}$, the available $\mathrm{P}$ contents were $10-20 \mathrm{mg} \mathrm{kg}^{-1}$, and the available $\mathrm{K}$ contents were $0.3-1.5 \mathrm{~g} \mathrm{~kg}^{-1}$.

\subsection{Soil comprehensive fertility index}

The soil comprehensive fertility indexes of different type grasslands ranged from 1.01 to 2.24 (Table 6). The soil comprehensive fertility index was significantly higher in AM, UM, AS and TS than AD, significantly higher in AD than LM and TDS, and significantly higher in TDS than TD, but no significant difference was found among others. The rank of soil comprehensive fertility index was TS $>$ AM $>$ AS $>$ UM $>$ AD $>$ LM $>$ TDS $>$ TD.

The soil fertility of Qilian mountain grassland was at a moderate or high level (Fig. 3). In terms of spatial distribution, the soil comprehensive fertility index was at a high level in eastern and western of Qilian Mountains, and the soil fertility in the central region was at a moderate level. There are only a few areas where the soil fertility of the grassland was at a low level, and distributed in the marginal regions of the western and central regions. The areas with the high, medium and low soil fertility accounted for $45.60 \%, 41.92 \%$ and $12.46 \%$ of the total grassland area of Qilian Mountains respectively.

\subsection{Limiting factors for grassland soil comprehensive fertility}

The soil fertility of different types of grasslands had different major limiting factors (Table 6). For example, the $\mathrm{pH}$, total $\mathrm{N}$ and SOM were the main factors limiting soil fertility in LM, and $\mathrm{pH}$ and available $\mathrm{P}$ were the main factors limiting soil fertility in UM, AM, TS and AS. The Soil bulk density, pH, total N, SOM and available P were the main factors limiting soil fertility in TD and TDS. Soil bulk density and available P were the main factors limiting soil fertility in AD. The limiting factors for the comprehensive soil fertility were shown in Fig.3.

\section{Discuss}

Soil organic matter content is closely related to soil fertility and soil health. The nitrogen, phosphorus, and potassium provide essential nutrients for plant growth and development, and are the main components of soil nutrients (Zhang et al., 2013; Zhou et al., 2016). The contents of SOM and available K were graded as level 2 (high) or above according to the classification of China second soil census standards (National Geographic Resource Science SubCenter, http://gre.geodata.cn). Available P was graded as level 4 with the content of $6.79-24.27 \mathrm{mg} \mathrm{kg}^{-}$

1. Soil density suitable for plant growth is generally within 1.14 to $1.26 \mathrm{~g} \mathrm{~cm}^{-3}$. In ours research, the average soil

Peer] reviewing PDF | (2020:06:50167:3:0:NEW 21 Jan 2021) 
188

189

190

191

192

193

194

195

196

197

198

199

200

201

202

203

204

205

206

207

208

209

210

211

212

213

214

215

216

217

218

219

220

221

222

223

224

bulk density of grasslands in Qilian mountain was $1.01 \mathrm{~g} \mathrm{~cm}^{-3}$, with a value of between $0.75-1.14 \mathrm{~g} \mathrm{~cm}^{-3}$ in most areas of the Qilian Mountains. The grassland soil comprehensive fertility index decreases from east to west. The spatial distribution and succession of grassland types decided the grassland soil fertility. From west to east, the grassland types are desert, typical grassland and meadow grassland mainly. As an indicator of dispersion degree of the sample, $\mathrm{CV}<10 \%$ means weak variation, $10-100 \%$ means medium variation and $>100 \%$ means strong variation. The results of our studies indicated that, except for soil $\mathrm{pH}$, which were weak variations, all the nutrient indicators were medium variable.

Grassland type is determined by climate, vegetation and soil ( $\mathrm{Hu}$ et al., 1978). As the substrate of grassland, soil physical and chemical properties of different types of grasslands provide important insight to understand grassland evolution (Gou et al., 2019; Li et al., 2019). Zhang et al (2019) found that the contents of total N, organic carbon and soluble organic carbon of different alpine types of grasslands were in an order of alpine meadow $>$ alpine meadow grassland $>$ alpine grassland $>$ alpine desert, and the differences between various alpine types of grasslands were significant. This study observed that the ranking of the different types of grasslands was desert type $>$ meadow type $>$ steppe type for soil bulk density, the ranking of total porosity were opposite to that of soil bulk density. Furthermore, the total N, SOM and soil comprehensive fertility index in different grassland types had significant differences. Since soil nutrients were mainly derived from the decomposition of animals, plants, microbial residues, litters, root exudates and soil parent materials, spatial heterogeneity of soil fertility distribution in different types of grasslands observed in this study indicated these grasslands were influenced through the different climate and vegetation (Wei et al., 2018). Soil organic matter mainly came from the decomposition of organic residual, but moisture and temperature were the dominant factors controlling the decomposition rate of organic matter. This was why Ren and $\mathrm{Hu}$ (2008) used precipitation and temperature accumulated as a first-class classification index to classify grassland types in Comprehensive and Sequential Classification System (Ren and Hu., 2008).

Evaluation factors affect the rationality and objectivity of evaluation results to a certain extent (Chen et al., 2019; Science - Soil Science, 2019). In many studies, the evaluation indicators of soil fertility mainly focused on nutrients such as soil organic matter, nitrogen, phosphorus and potassium (Chen et al., 2019; Science-Soil Science, 2019; Yu et al., 2018). The soil bulk density and total porosity can reflect the status of soil fertility from different angle as soil compactness, permeability, infiltration performance and water holding capacity (Garrigues et al., 2012). The modified Nemerow formula highlights the effect of the minimum factor on soil fertility, reflecting the law of the limiting factor of plant growth in ecology (An et al., 2015), and the soil minimum factor can be identified according to the minimum value of the Fi in Nemerow formula. In ours study, the soil fertility of different types of grasslands had different main limiting factors. Such as $\mathrm{pH}$, total $\mathrm{N}$ and SOM were the main factors limiting soil fertility in LM, and $\mathrm{pH}$ and available $\mathrm{P}$ were the main factors limiting soil fertility in UM, AM, TS and AS. The Soil bulk density, $\mathrm{pH}$, total N, SOM and available P were the main factors limiting soil fertility in TD and TDS. Soil bulk density and available $\mathrm{P}$ were the main factors limiting soil fertility in AD. Nemerow index method can objectively reflect the comprehensive fertility characteristics of grassland soil, but many studies have not analyzed the spatial distribution characteristics of soil fertility in depth (Bao et al., 2012; Fan, et al., 2012). Ours research combined GIS and soil science to draw a spatial distribution map of grassland soil fertility in Qilian mountain, which more intuitively

Peer) reviewing PDF | (2020:06:50167:3:0:NEW 21 Jan 2021) 
225

226

227

228

229

230

231

232

233

234

235

236

237

238

239

240

241

242

243

244

245

246

247

248

249

250

251

252

253

254

255

256

257

258

259

260

261

262

263

264

265

266

267

268

reflected the distribution of grassland soil fertility. In ours study, the areas with high, medium and low soil fertility accounted for the total grassland area of Qilian Mountains was $45.60 \%, 41.92 \%$ and $12.46 \%$.

Grassland was an important foundation for the construction of the Qilian Mountain ecosystem. Based on the research results, the actual distribution of grassland types, and reasonable management could promote benign and sustainable development of grassland ecosystems.

\section{Conclusions}

The results of soil fertility indexes and their spatial distribution of grasslands in Qilian mountain showed that, except for the low-available P content, all the soil fertility indexes had reached level 2 and above according to China's second soil census standard, while soil bulk density was relatively low and $\mathrm{pH}$ was relatively high. The soil comprehensive fertility index was in a ranking order of TS $>\mathrm{AM}>\mathrm{AS}>\mathrm{UM}>\mathrm{AD}>\mathrm{LM}>\mathrm{TDS}>\mathrm{TD}$, and the areas with high, medium and low soil fertility accounted for $63.19 \%, 34.24 \%$ and $2.57 \%$ of the total grassland area respectively. Soil fertility of different grassland types had different main limiting factors, for instance, the $\mathrm{pH}$, total $\mathrm{N}$ and SOM were the main factors limiting soil fertility in LM, while they were $\mathrm{pH}$ and available $\mathrm{P}$ for $\mathrm{UM}, \mathrm{AM}$, TS and AS. The typical grasslands and meadows may need to apply phosphorus, and desert grasslands to apply both nitrogen and phosphorus to improve comprehensive soil fertility and grassland productivity

\section{Acknowledgements}

This study was supported by National Natural Science Foundation of China (31160475; 61401439); A

new round of grassland Reward and subsidy Benefit evaluation and grassland ecological evaluation in

Gansu Province (XZ20191225).

\section{Reference}

Abdalla K., Mutema M., Chivenge P., Everson C., \& Chaplot V. 2018. Grassland degradation significantly enhances soil $\mathrm{CO}_{2}$ emission. Catena, 167, 284-292.

An K, Xie X P, Zhang H Z, Zhou H. 2015. Spatial pattern and impact factors of soil fertility in West Lake Scenic Area. Chinese Journal of Ecology, 34(4): 1091-1096. (in Chinese) DOI: 10.13292/j.1000 -4890.20150304.020

Bao Y X, Xu M G, Lu F T, Huang Q H, Lie J. 2012. Evaluation method on soil fertility under long- term fertilization. Scientia Agricultura Sinica, 45(20): 4197-4204. (in Chinese) DOI: CNKI: SUN: ZNYK.0.201220-012

Brevik, E. C., Homburg, J. A., Miller, B. A., Fenton, T. E., Doolittle, J. A., \& Indorante, S. J. 2016. Selected highlights in American soil science history from the 1980s to the mid-2010s. CATENA, 146, 128-146. doi:10.1016/j.catena.2016.06.021

Chen S, Lin BW, Li Yan Q, Zhou S N. 2019. Spatial and temporal changes of soil properties and soil fertility evaluation in a large grain-production area of subtropical plain, China. Geoderma, 357: 113937. https://doi.org/10.1016/j.geoderma.2019.113937

Chen, L F, He, Z B, Zhu X, Du J, Yang J J, \& Li J. 2016. Impacts of afforestation on plant diversity, soil properties, and soil organic carbon storage in a semi-arid grassland of northwestern China. CATENA, 147, 300-307. Doi: 10.1016/j.catena.2016.07.009

Cheng T Y, Jia Y F, Wang J A. 2019. Soil Conservation Function of Qilian Mountains National Nature Reserve Based on InVEST Model. Arid Zone Research. (in Chinese). http://kns.cnki. net $/ \mathrm{kcms} / \mathrm{detail} / 65.1095 . x .20191121 .0940 .004 . \mathrm{html}$

Clanet, V. 1980. In increasing or maintaining the fertility of grassland and herds: phosphoric acid plays a key role. Fourrages Actualites Supplement A Lelevage Bovin Ovin Caprin, 9-13.

Cui X X, Gao Y, Lu Y Z. 2010. Spatial variability of soil fertility in Daxing District of Beijing. Transactions of the CSAE, 26 (9): 327-333. (in Chinese) Doi: CNKI:SUN:NYGU.0.2010-09-056.

Dong S K, Wen L, Li Y Y, Wang X X, Zhu L, Li X Y. 2012. Soil-quality effects of grassland degradation and

Peer] reviewing PDF | (2020:06:50167:3:0:NEW 21 Jan 2021) 
restoration on the Qinghai-Tibetan Plateau. Soil Science Society of America Journal, 76, 2256-2264.

Fan H R, Li Y P, Wu S X. 2012. Study on the Comprehensive Evaluation of the Soil Fertility Quality of the Green Land in Qinhuangdao. Advanced Materials Research, 573-574:191-194. Doi: 10.4028/www.scientific.net/AMR.573-574.191

Fayiah Moses, Dong S K, Li Y, Xu Y D, Gao X X, Li S, Shen H, Xiao J N, Yang Y F, Wessell Kelly. 2019. The relationships between plant diversity, plant cover, plant biomass and soil fertility vary with grassland type on Qinghai-Tibetan Plateau. Agriculture, Ecosystems \& Environment, 286, 106659. Doi:10.1016/j.agee.2019. 106659

Garrigues E, Corson M S, Angers D A, Werf H M.G., Walter C. 2012. Soil quality in life cycle assessment: Towards development of an indicator. Ecol Indic, 18: 434-442. Doi: 10.1016/j.ecolind.2011. 12.014.

Gou X, Hu J, Chen Y, Wei X, Du Z, Zhou Q. 2019. The effect of artificial vegetation recovery on the soil nutrients and enzyme activities in sub humid desert land on the southeast Qinghai-Tibetan Plateau, China. Ecological Engineering, 139, 105528. Doi: 10.1016/j.eco leng.2019.06.023

Guo J, Ren Z G, Liu X N. 2011. An improved method for spatial interpolation ofmeteorological data based on GIS modules-A case study in Gansu Province, Grassland and Turf, 31(4):41-45. ( in Chinese)

Harpole W S, Potts D L, Suding K N. 2007. Ecosystem responses to water and nitrogen amendment in a California grassland. Global change biology, 13(11): 2341-2348.

Hao A H, Xue X A, Peng F, You Q G, Liao J, Duan H C, Huang C H, Dong S Y. 2020. Different vegetation and soil degradation characteristics of a typical grassland in the Qinghai-Tibetan Plateau. Acta Ecologica Sinica, 40(3). (in Chinese) http://kns.cnki.net/kcms/detail/11.2031.Q. 20191120.0936.052.html

Henry Oppong Tuffour, ALI BAGHERZADEH, Leo Paapa Tattrah, Jesús Rodrigo-Comino. 2020. Using fuzzyAHP and parametric technique to assess soil fertility status in Northeast of Iran. Journal of Mountain ence, 17(4):931-948. Doi: 10.1007/s11629-019-5666-6

Hu S J, Hu R, Pu Y L, Wang A B, Xiang S, Long G F, Zhang S R, Jia Y X, Xu X X. 2018. Influence of ecological restoration on soil biological fertility in desertified grassland. Pratacultural Science, 5(11): 2550-2560. Doi: 10.11829/j.issn.1001-0629. 2018-0069.

Hua S, Li X, J, Zhang J T, Yu H J. 2018. Evaluation of Heavy Metal Pollution in the Soils around the Brownfield Based on the Modified Nemerow Index Method. Environmental Protection Science, 44(2): 98-102. Doi: 10.16803/j.cnki.issn.1004-6216.2018.02.019.

Hu Z Z, Zhang P J, Nan Z B. 1978. Grassland types in Gansu Province. Journal of Gansu Agricultural University, Doi: 10.13432/j.cnki.jgsau.1978.01.001.

http://www.qilianshan.com.cn/html/1/271/160/168/index.html

Jin H F, Shi D M, Chen Z F, Liu Y J, Lu Y B, Yang X. 2018. Evaluation indicators of cultivated layer soil quality for red soil slope farmland based on cluster and PCA analysis. Transactions of the Chinese Society of Agricultural Engineering, 34(7): 155- 164. (in Chinese) Doi: 10.11975/j.issn. 1002-6819. 2018. 07.020

Li J, Min Q W, Li W H, Bai Y Y, DhrubaBijayaG. C., Yuan Z. 2014. Spatial variability analysis of soil nutrients based on GIS and geostatistics: acase study of Yisa township, Yunnan, China. Journal of Resources and Ecology, 5(4) :348-355. Doi:10.5814/j.issn.1674-764x.2014.04.010

Li W, Jia X, Li M, Wu H. 2019. Insight into the vertical characteristics of dissolved organic matter in 5-m soil profiles under different land-use types on the Loess Plateau. Science of The Total Environment, 692: 613-621. Doi:10.1016/j.scitotenv.2019.07.339

Li Y G, Li Z X, Feng Q, Wei W, Feng Q, Yang J, Lv Y M, Guai J, Yuan R F, Zhang B J. 2019. Research on the development of the ecological protection of the Qilian Mountains based on ecological redline. Acta Ecologica Sinica, 39(7): 2343-2352. (in Chinese) Doi: 10.5846/stxb 201802250383.

Liu X N, Guo J, Ren Z G, Hu Z Z, Chen Q G, Zhang D G, Zhu H Z. 2012. Chinese rangeland CSCS classification based on optimal simulation for spatial distribution of meteorological factors. Transactions of the Chinese Society of Agricultural Engineering (Transactions of the CSAE), 28(9): 222-229. (in Chinese) Doi:10.3969/j.issn.1002-6819.2012.09.037.

Ma J, Liu X D, Li G, Zhao W J, Wang S L, Wang R X, Zhao Y H. 2019.Evaluation on soil fertility quality of Picea crassifolia forest in middle Qilian Mountains. Arid Land Geography. (in Chinese ) http://kns.cnki.net/kcms/detail/ 65.1103.X.20191008.1740.015.html

$\mathrm{Mu} \mathrm{S}$, Zhou S, Chen Y, Li, J L, Ju W M, Odeh I.O.A.. 2013. Assessing the impact of restoration-induced land conversion and management alternatives on net primary productivity in Inner Mongolian grassland, China. Global \& Planetary Change, 108:29-41. Doi: 10.1016/j.gloplacha.2013.06.007.

Miller, A. D., Vaske, J. J., Squires, J. R., Olson, L. E., \& Roberts, E. K. 2016. Does Zoning Winter Recreationists Reduce Recreation Conflict? Environmental Management, 59(1), 50-67. Doi:10. 1007/s00267-016-0777-0 
National Geographic Resource Science SubCenter, National Earth System Science Data Center, National Science \& Technology Infrastructure of China (http://gre.geodata.cn)

Nelson, D. W., \& Sommers, L. E. 1996. Total carbon, organic carbon, and organic matter. In D. L. Sparks, A. L. Page, P. A. Helmke, R. H. Loeppert, P. N. Soltanpour, M. A. Tabatabai, C. T. Johnston, \& M. E. Sumner (Eds.), Methods of soil analysis. Part 3: Chemical methods (pp. 961-1010). Madison: Soil Science Society of America, Inc., American Society of Agronomy, Inc.

Nemerow, N. L. 1974. Scientific Stream Pollution Analysis, McGraw-Hill, New York.

Nie Y, Yu J, Wu Y, Wu, Y G, Yu L, Jing Y, Zhou Y. 2016. A Comprehensive Evaluation of Soil Fertility of Cultivated Land: A GIS-Based Soil Basic Niche-Fitness Model. Communications in Soil Science \& Plant Analysis, 00103624.2016.1146748. Doi: 10.1080/00103624.2016.1146748.

Nistor, Mărgărit., M. 2016. Spatial distribution of climate indices in the Emilia - Romagna region. Meteorological Applications, 23(2):304-313. DOI: 10.1002/met.1555

NY/T 2997-2016, Grassland classification[S]. China: China Standard Press, 2016.

Peng G, Bing W, Guangpo G, Zhang G K. 2013. Spatial distribution of soil organic carbon and total nitrogen based on GIS and geostatistics in a small watershed in a Hilly area of Northern China. PLoS ONE, 8(12): e83592. Doi:10.1371/journal.pone.0083592.

Qi J, Nie Z N, Jiao T, \& Zhang D G. (2015). Phosphorus and Defoliation Interact and Improve the Growth and Composition of the Plant Community and Soil Properties in an Alpine Pasture of Qinghai-Tibet Plateau. PLOS ONE, 10(10), e0141701. Doi:10.1371/journal.pone.0141701

Qu T B, Du W C, Yuan X, Yang Z M, Yu L J. 2016. Impacts of Grazing Intensity and Plant Community Composition on Soil Bacterial Community Diversity in a Steppe Grassland. PLoS ONE, 11(7): e0159680. Doi: 10.1371/journal.pone.0159680

Ren J Z, Hu Z Z, Zhao J, Zhang D G, Hou F J, Lin H L, Mu X D. 2008. A Grassland classification system and its application in China. The Rangeland Journal, 30: 199-209.

Science-Soil Science. 2019. Studies from University of Ege Reveal New Findings on Soil Science (Evaluation of soil fertility in citrus planted areas by geostatistics analysis method) [M]. Science Letter. https://kns.cnki.net/KCMS/detail/detail.aspx.dbcode.

Si J H, Feng Q, Yu T F, Su Y H. 2009. Spatial heterogeneity of soil nutrients in Ejina oasis. Chinese Journal of Ecology, 28(12): 2600-2606. (in Chinese) Doi: http://ir.casnw.net/handle/362004/ 10023

Shahab H, Emami H, Haghnia G H , Arimi A.K. 2013, Pore Size Distribution as a Soil Physical Quality Index for Agricultural and Pasture Soils in Northeastern Iran. Pedosphere, (03):42-50. Doi: CNKI:SUN:TRQY.0.201303-007

Soil Physics institute, Nanjing Institute of Soil Science, Chinese Academy of Sciences. 1978. Soil physical properties determination method[M]. Beijing; Science Press.

Sousa G G D, Azevedo B M D, Albuquerque A H P, Mesquita J B R, Viana T V A.. 2012. Características agronômicas do amendoinzeiro sob irrigação com águas salinas em solo com biofertilizantes. Agro@mbiente On-line. Doi: 10.18227/1982-8470ragro.v6i2.708

Su T T, Ma H B, Zhou Y, Jia X Y, Hu Y L. 2019. Response of typical steppe grassland soil physical and chemical properties to various ecological restoration measures in the Ningxia Loess Hill Region. Acta Prataculturae Sinica, 28(4): 34- 46. (in Chinese) Doi: 10. 11686/cyxb2018247

Wei W, Zhou J J, Shi R Z. 2018. Relationship between Root Distribution Characteristics and Soil Factors in Different Grassland Communities in Tibet. Chinese Journal of Grassland, 40(6): 33-38. (in Chinese) Doi: 10.16742/j.zgcdxb.2018-06-05.

Wang, Q., Yang, Q., Guo, H., Xiao, X., Jin, H., Li, L., Wu, Q. 2018. Hydrothermal variations in soils resulting from the freezing and thawing processes in the active layer of an alpine grassland in the Qilian Mountains, northeastern Tibetan Plateau. Theoretical and Applied Climatology. Doi:10.1007/s00704-018-2529-y

Wang G H., Ren J Z., Zhang Z H.. 2001. A Study on the population diversity of plant community, in Hexi mountain-oasis-desert area: General features. ACT A PRATACULTURAE SINICA, 10(1): 1-12. Doi: 10045759(2001) 01-0001-12

Wang Z Q, Zhang Y Z, Yang Y, Zhou W, Gang C C, Zhang Y, Li J L, An R, Wang K, Inakwu Odeh, Qi J G. 2016. Quantitative assess the driving forces on the grassland degradation in the Qinghai-Tibetan Plateau, in China. Ecological Informatics, 33: 32-44.

Wang S H, Li M Cn, Su M. 2007. Research on comprehensive evaluation to land consolidation supported by GIS: a case study of Shaoshan city in Hunan province//Geoinformatics: Geospatial Information Technology \& Applications. International Society for Optics and Photonics, DOI: 10.1117/12.765491. 
380
Wuest S B. 2015. Seasonal Variation in Soil Bulk Density, Organic Nitrogen, Available Phosphorus, and pH. Soil Science Society of America Journal, 79(4). DOI: 10.2136/sssaj2015.02.0066

Yu P J, Han D L, Liu S W, Wen X, Huang Y X, Jia H T. 2018. Soil quality assessment under different land uses in an alpine grassland. Catena, 171: 280-287. Doi.org/10.1016/j.catena.2018. 07.021.

Zhang L N, Li J, Fan P, Cao Y. 2013. Distribution of soil N P K nutrient content in deep soil profile of typical apple orchards on the Loess Plateau. Acta Ecologica Sinica, 33(6):1907-1915. (in Chinese) Doi: CNKI:SUN:STXB.0.2013-06-026

Zhang M M, Chen W, Lin I, Zhang D G, Wu Y X, Xiao H L. 2019. A study of soil nutrient characteristics and soil soluble organic carbon levels in different types of alpine grassland in Qinghai Province. Acta Prataculturae Sinica, 28(3): 20-08. (in Chinese) Doi: 10.11686/ cyxb2018540.

Zhou W, Wang W J, Zhang B, Xiao L, Lv H L, He X Y. 2017. Soil fertility evaluation for urban forests and green spaces in Changchun City. Acta Ecologica Sinica, 37(4) :1211-1220. Doi: 10.5846/stxb 201604180723

Zhou W, Wang W J, He X Y, Zhang B, Xiao L, Lv H L, Wei C H. 2018. Soil Fertility and Spatial Variability of Urban Green Land in Harbin. SCIENTIA SILVAE SINICAE, 54(9): 9-17. Doi:10. 11707/j.10017488.20180902 .

Zhou Y, Biswas A, Ma Z Q, Lu Y L, Chen Q X, Shi Z. 2016. Revealing the scale- specific controls of soil organic matter at large scale in Northeast and North China Plain. Geoderma, (271): 71-79. Doi:10.1016/j.geoderma.2016.02.006 


\section{Table $\mathbf{1}$ (on next page)}

nformation of the sample sites, Classification criterion of soil nutrients, Grading criterion for various soil properties in the Nemerow grading method, Criteria for determining the organic matter, total nitrogen and bulk density of grassland soi

nformation of the sample sites, Classification criterion of soil nutrients, Grading criterion for various soil properties in the Nemerow grading method, Criteria for determining the organic matter, total nitrogen and bulk density of grassland soils with different degradation degrees,Descriptive statistics in various studied parameters of grassland soil in Qilian Mountain Nature Reserve 
Table 1 Information of the sample sites (NY/T 2997-2016, 2016)

\begin{tabular}{|c|c|c|c|c|}
\hline $\begin{array}{l}\text { Type } \\
\text { Grassland }\end{array}$ & $\begin{array}{l}\text { Altitude } \\
\mathrm{m}\end{array}$ & $\begin{array}{l}\text { longitude and } \\
\text { latitude }\end{array}$ & $\begin{array}{l}\text { Main plant } \\
\text { species }\end{array}$ & $\begin{array}{c}\text { Coverage } \\
\%\end{array}$ \\
\hline $\begin{array}{l}\text { Lowland meadow } \\
\text { (LM) }\end{array}$ & 1364 & $\begin{array}{l}39^{\circ} 40^{\prime} 35.02^{\prime \prime} \mathrm{N} \\
99^{\circ} 8^{\prime} 45.09^{\prime \prime} \mathrm{E}\end{array}$ & $\begin{array}{l}\text { Phragmites australis (Cav.) Trin. ex Steud, } \\
\text { Achnatherum splendens, sophora alopecuroides L. }\end{array}$ & 48.33 \\
\hline $\begin{array}{l}\text { Upland meadow } \\
\text { (UM) }\end{array}$ & 3114 & $\begin{array}{l}37^{\circ} 11^{\prime} 36.47^{\prime \prime} \mathrm{N} \\
102^{\circ} 43^{\prime} 42.73^{\prime \prime} \mathrm{E}\end{array}$ & $\begin{array}{c}\text { Potentilla anserina } \text { L., Poa annua } \text { L., Elymus nutans } \\
\text { griseb., Melissilus ruthenicus (L.) Peschkova, } \\
\text { Artemisia annua } \text { L.. }\end{array}$ & 81.67 \\
\hline $\begin{array}{l}\text { Alpine meadow } \\
\quad(\mathrm{AM})\end{array}$ & 2977 & $\begin{array}{l}37^{\circ} 10^{\prime} 48.66^{\prime \prime} \mathrm{N} \\
102^{\circ} 47^{\prime} 13.83^{\prime \prime} \mathrm{E}\end{array}$ & $\begin{array}{l}\text { Polygonum viviparum L., Kobresia myosuroides } \\
\text { (Villars) Fiori, Melissilus ruthenicus(L.). Peschkova, } \\
\text { artemisia annua Linn., Saussurea japonica DC. }\end{array}$ & 85.00 \\
\hline $\begin{array}{l}\text { Temperate steppe } \\
\text { (ST) }\end{array}$ & 2817 & $\begin{array}{l}37^{\circ} 22^{\prime} 13.68^{\prime \prime} \mathrm{N} \\
102^{\circ} 40^{\prime} 44.93^{\prime \prime} \mathrm{E}\end{array}$ & $\begin{array}{c}\text { Poa annua L., Kobresia myosuroides (Villars) Fiori, } \\
\text { Stipa capillata Linn., Potentilla anserina L., } \\
\text { Artemisia annua Linn. }\end{array}$ & 85.00 \\
\hline $\begin{array}{l}\text { Alpine steppe } \\
\text { (AT) }\end{array}$ & 3735 & $\begin{array}{l}39^{\circ} 16^{\prime} 32.99^{\prime \prime} \mathrm{N} \\
97^{\circ} 42^{\prime} 52.57^{\prime \prime} \mathrm{E}\end{array}$ & $\begin{array}{c}\text { Stipa purpurea, kobresia myosuroides (Villars) Fiori, } \\
\text { Poa annua L., Potentilla anserina L., Androsace } \\
\text { umbellate }\end{array}$ & 85.00 \\
\hline $\begin{array}{l}\text { Temperate desert } \\
\text { Steppe (TDS) }\end{array}$ & 2139 & $\begin{array}{l}38^{\circ} 57^{\prime} 57.23^{\prime \prime} \mathrm{N} \\
99^{\circ} 47^{\prime} 41.95^{\prime \prime} \mathrm{E}\end{array}$ & $\begin{array}{c}\text { Sympegma regelii Bunge, Salsola collina Pall., Allium } \\
\text { polyrhizum Turcz, Stipa capillata Linn., Ajania } \\
\text { nematoloba }\end{array}$ & 43.75 \\
\hline $\begin{array}{l}\text { Temperate Desert } \\
\text { (TD) }\end{array}$ & 1358 & $\begin{array}{l}39^{\circ} 29^{\prime} 29.11^{\prime \prime} \mathrm{N} \\
99^{\circ} 18^{\prime} 45.00^{\prime \prime} \mathrm{E}\end{array}$ & $\begin{array}{c}\text { Nitraria tangutorum Bobr, Nitraria sphaerocarpa } \\
\text { Maxim, Suaeda glauca (Bunge) Bunge, Sympegma } \\
\text { regelii Bunge }\end{array}$ & 31.67 \\
\hline $\begin{array}{l}\text { Alpine desert } \\
\text { (AD) }\end{array}$ & 4290 & $\begin{array}{l}39^{\circ} 15^{\prime} 34.39^{\prime \prime} \mathrm{N} \\
97^{\circ} 45^{\prime} 6.70^{\prime \prime} \mathrm{E}\end{array}$ & $\begin{array}{c}\text { Rhodiola rosea L., Saussurea japonica DC., Kobresia } \\
\text { myosuroides (Villars) Fiori }\end{array}$ & 28.33 \\
\hline
\end{tabular}

2 
Table 2 (on next page)

Table 2. Classification criteria used for soil index 
1

Table 2. Classification criteria used for soil index

2 
Table 3 (on next page)

Table 3 Grading criterion for various soil properties in the Nemerow grading method 
1

Table 3 Grading criterion for various soil properties in the Nemerow grading method

\begin{tabular}{ccccccccc}
\hline Soil properties & & $\begin{array}{c}\text { Soil bulk } \\
\text { density } \\
\mathrm{g} \mathrm{cm}^{-3}\end{array}$ & $\begin{array}{c}\text { total } \\
\text { porosity } \\
\%\end{array}$ & $\mathrm{pH}$ & $\begin{array}{c}\mathrm{SOM} \\
\mathrm{g} \mathrm{kg}^{-1}\end{array}$ & $\begin{array}{c}\text { Total N } \\
\mathrm{g} \mathrm{kg}^{-1}\end{array}$ & $\begin{array}{c}\text { Available P } \\
\mathrm{mg} \mathrm{kg}^{-1}\end{array}$ & $\begin{array}{c}\text { Available K } \\
\mathrm{g} \mathrm{kg}^{-1}\end{array}$ \\
\hline Classification & $\mathrm{x}_{\mathrm{p}}$ & 0.95 & 0.50 & 7 & 30 & 2.00 & 20 & 0.20 \\
index of & $\mathrm{x}_{\mathrm{c}}$ & 1.10 & 0.40 & 8 & 20 & 1.50 & 10 & 0.10 \\
Nemorow & $\mathrm{x}_{\mathrm{a}}$ & 1.25 & 0.30 & 9 & 10 & 0.75 & 5 & 0.05 \\
\hline
\end{tabular}

$2 \mathrm{x}_{\mathrm{a}}, \mathrm{x}_{\mathrm{c}}$, and $\mathrm{x}_{\mathrm{p}}$ are the classification indexes

3 


\section{Table 4 (on next page)}

Table 4. Descriptive statistics of grassland soils in Qilian mountain nature reserve 
1
2
3

\begin{tabular}{|c|c|c|c|c|c|}
\hline Item & MIN & MAX & Mean & SD & CV\% \\
\hline Soil bulk density $\mathrm{g} \mathrm{cm}^{-3}$ & 0.77 & 1.32 & 1.01 & 0.18 & 17.88 \\
\hline Total porosity $\%$ & 35.36 & 58.83 & 48.25 & 7.90 & 16.38 \\
\hline $\mathrm{pH}$ & 7.63 & 8.54 & 8.07 & 0.38 & 4.71 \\
\hline Total $\mathrm{N} \mathrm{g} \mathrm{kg}^{-1}$ & 0.63 & 4.97 & 2.38 & 1.8 & 75.49 \\
\hline Available $\mathrm{P} \mathrm{mg} \mathrm{kg}^{-1}$ & 6.79 & 24.27 & 12.81 & 5.52 & 43.09 \\
\hline Available $\mathrm{K} \mathrm{g} \mathrm{kg}^{-1}$ & 0.21 & 1.06 & 0.40 & 0.27 & 68.00 \\
\hline SOM g kg-1 & 4.99 & 131.52 & 51.23 & 48.83 & 95.32 \\
\hline
\end{tabular}

4 


\section{Table 5 (on next page)}

Table 5 Soil physical and chemical properties in different Grassland types in Qilian mountain Nature Reserve 
Table 5 Soil physical and chemical properties in different Grassland types in Qilian mountain Nature Reserve

\begin{tabular}{|c|c|c|c|c|c|c|c|}
\hline Grassland Type & $\begin{array}{l}\text { Soil bulk density } \\
\mathrm{g} \mathrm{cm}^{-3}\end{array}$ & $\begin{array}{c}\text { Total porosity } \\
\%\end{array}$ & $\mathrm{pH}$ & $\begin{array}{c}\text { Total N } \\
\mathrm{g} \mathrm{kg}^{-1} \\
\end{array}$ & $\begin{array}{c}\text { Available P } \\
\text { mg kg-1 }^{-1}\end{array}$ & $\begin{array}{c}\text { Available K } \\
\mathrm{g} \mathrm{kg}^{-1}\end{array}$ & $\begin{array}{l}\mathrm{SOM} \\
\mathrm{g} \mathrm{kg}^{-1} \\
\end{array}$ \\
\hline LM & $1.05 \pm 0.09 \mathrm{bc}$ & $43.65 \pm 4.83 \mathrm{~cd}$ & $8.51 \pm 0.04 \mathrm{a}$ & $0.64 \pm 0.10 \mathrm{~d}$ & $24.27 \pm 3.55 \mathrm{a}$ & $1.06 \pm 0.91 \mathrm{a}$ & $12.67 \pm 1.63 \mathrm{~cd}$ \\
\hline UM & $0.95 \pm 0.07 \mathrm{~cd}$ & $48.73 \pm 2.06 \mathrm{bc}$ & $7.97 \pm 0.24 b$ & $2.01 \pm 0.51 \mathrm{c}$ & $12.34 \pm 2.97 b$ & $0.45 \pm 0.06 \mathrm{~b}$ & $36.87 \pm 16.45 c$ \\
\hline $\mathrm{AM}$ & $0.83 \pm 0.09 \mathrm{de}$ & $51.59 \pm 5.45 b$ & $7.76 \pm 0.26 \mathrm{~d}$ & $4.81 \pm 0.13 \mathrm{a}$ & $13.73 \pm 7.54 \mathrm{ab}$ & $0.30 \pm 0.15 b c$ & $116.46 \pm 28.35 \mathrm{a}$ \\
\hline $\mathrm{TS}$ & $0.77 \pm 0.03 \mathrm{df}$ & $54.98 \pm 1.92 \mathrm{ab}$ & $7.63 \pm 0.10 \mathrm{e}$ & $4.97 \pm 0.78 \mathrm{a}$ & $14.94 \pm 5.69 \mathrm{ab}$ & $0.30 \pm 0.06 \mathrm{c}$ & $131.52 \pm 14.33 \mathrm{a}$ \\
\hline AS & $0.91 \pm 0.05 \mathrm{~d}$ & $58.83 \pm 2.50 \mathrm{a}$ & $7.83 \pm 0.03 b c$ & $3.36 \pm 0.35 b$ & $13.65 \pm 6.95 \mathrm{ab}$ & $0.35 \pm 0.08 b c$ & $65.56 \pm 20.49 b$ \\
\hline TDS & $1.14 \pm 0.09 b$ & $52.53 \pm 1.06 \mathrm{~b}$ & $8.50 \pm 0.03 \mathrm{a}$ & $0.77 \pm 0.12 \mathrm{~d}$ & $7.96 \pm 0.65 b$ & $0.21 \pm 0.03 \mathrm{c}$ & $13.18 \pm 1.94 \mathrm{~cd}$ \\
\hline $\mathrm{TD}$ & $1.32 \pm 0.06 \mathrm{a}$ & $35.36 \pm 4.69 \mathrm{e}$ & $8.54 \pm 0.05 a$ & $0.63 \pm 0.08 \mathrm{~d}$ & $8.81 \pm 2.22 b$ & $0.32 \pm 0.05 b c$ & $4.99 \pm 0.99 \mathrm{~d}$ \\
\hline $\mathrm{AD}$ & $1.11 \pm 0.06 \mathrm{~b}$ & $40.32 \pm 2.18 \mathrm{de}$ & $7.84 \pm 0.04 b c$ & $1.88 \pm 0.07 \mathrm{c}$ & $6.79 \pm 0.97 b$ & $0.24 \pm 0.04 \mathrm{c}$ & $28.65 \pm 1.90 \mathrm{~cd}$ \\
\hline
\end{tabular}

2 Note: Data are presented as the mean \pm SD; Different small letters in the same column mean significant difference at 0.05 level. TS, Temperate steppe; AM, Alpine meadow; AS,

3 Alpine steppe; UM, Upland meadow; AD, Alpine desert; TDS, Temperate Desert Steppe; LM, Lowland meadow; TD, Temperate Desert. 
Table 6(on next page)

Table 6 Comprehensive evaluation of different Grassland Types in Qilian mountain Nature Reserve soil fertility using Nemerow index 
4 Table 6 Comprehensive evaluation of different Grassland Types in Qilian mountain Nature Reserve soil fertility using Nemerow index

\begin{tabular}{|c|c|c|c|c|c|c|c|c|c|}
\hline \multirow[b]{2}{*}{ rassland Type } & \multicolumn{7}{|c|}{$\mathrm{F}_{\mathrm{i}}$} & \multirow[b]{2}{*}{$\overline{\mathrm{Fi}}$} & \multirow[b]{2}{*}{$\mathrm{F}$} \\
\hline & Soil bulk density & $\begin{array}{c}\text { Total } \\
\text { porosity }\end{array}$ & $\mathrm{pH}$ & $\begin{array}{c}\text { Total } \\
\mathrm{N}\end{array}$ & $\begin{array}{c}\text { Availa-ble } \\
\text { P }\end{array}$ & $\begin{array}{c}\text { Availa-ble } \\
\text { K }\end{array}$ & SOM & & \\
\hline LM & 2.67 & 2.37 & 1.49 & 0.85 & 3.00 & 3.00 & 1.27 & 2.09 & $1.37 \mathrm{c}$ \\
\hline UM & 3.00 & 2.87 & 2.03 & 3.00 & 2.23 & 3.00 & 3.00 & 2.73 & $2.06 \mathrm{a}$ \\
\hline $\mathrm{AM}$ & 3.00 & 3.00 & 2.24 & 3.00 & 2.37 & 3.00 & 3.00 & 2.80 & $2.17 \mathrm{a}$ \\
\hline TS & 3.00 & 3.00 & 2.37 & 3.00 & 2.49 & 3.00 & 3.00 & 2.84 & $2.24 \mathrm{a}$ \\
\hline AS & 3.00 & 3.00 & 2.17 & 3.00 & 2.37 & 3.00 & 3.00 & 2.79 & $2.14 \mathrm{a}$ \\
\hline TDS & 1.73 & 3.00 & 1.50 & 1.03 & 1.59 & 3.00 & 1.32 & 1.88 & $1.30 \mathrm{c}$ \\
\hline $\mathrm{TD}$ & 1.06 & 2.54 & 1.46 & 0.84 & 1.76 & 3.00 & 0.50 & 1.59 & $1.01 \mathrm{~d}$ \\
\hline $\mathrm{AD}$ & 1.93 & 2.03 & 2.16 & 2.76 & 1.36 & 3.00 & 2.87 & 2.30 & $1.62 \mathrm{~b}$ \\
\hline
\end{tabular}

6 Note: TS, Temperate steppe; AM, Alpine meadow; AS, Alpine steppe; UM, Upland meadow; AD, Alpine desert; TDS,

7 Temperate Desert Steppe; LM, Lowland meadow; TD, Temperate Desert.

8

9 
Figure 1

Fig.1 The simulated samples of different grassland type patches spatial distribution

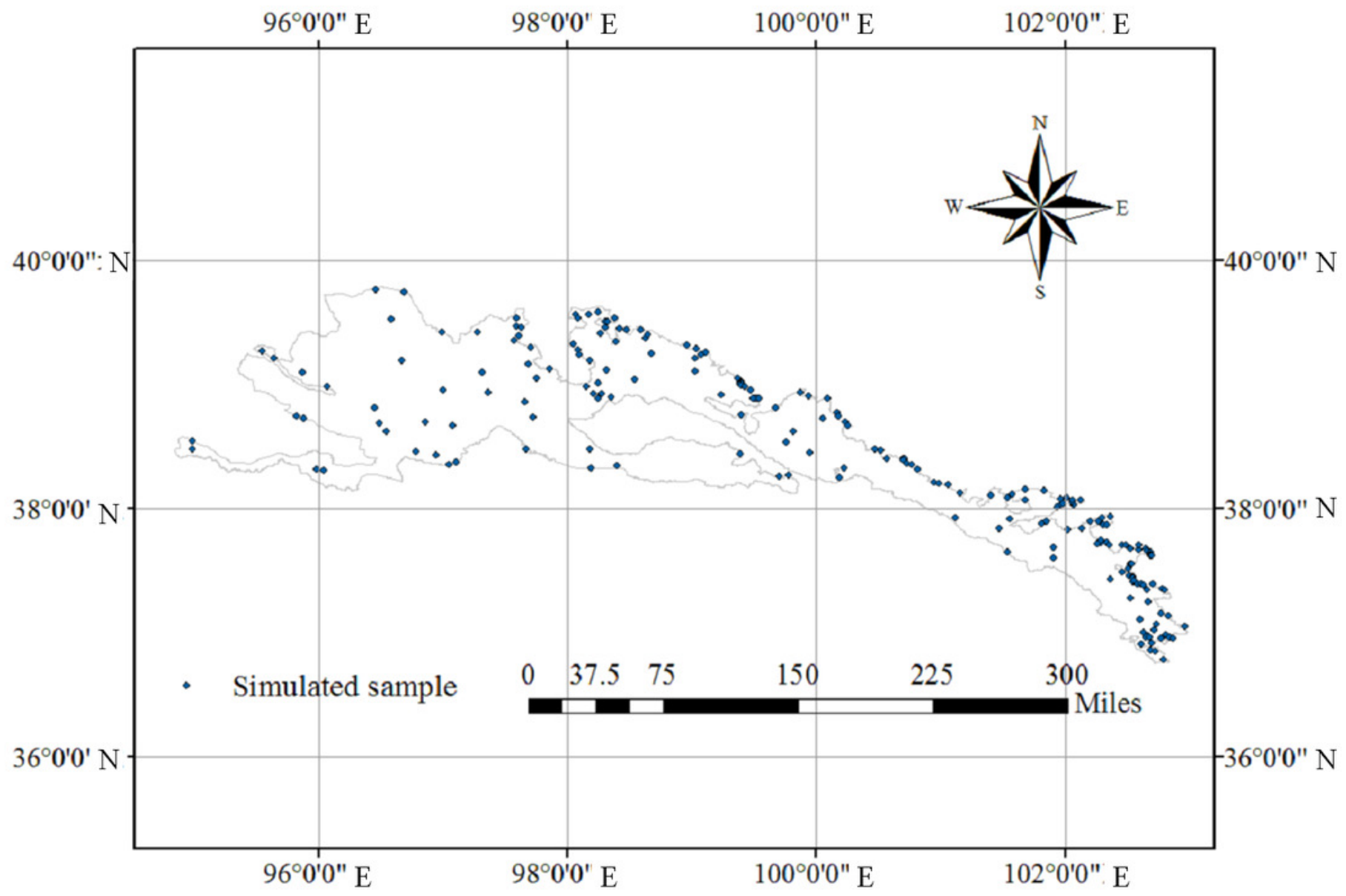


Figure 2

Fig.2 Soil physical and chemical spatial distribution
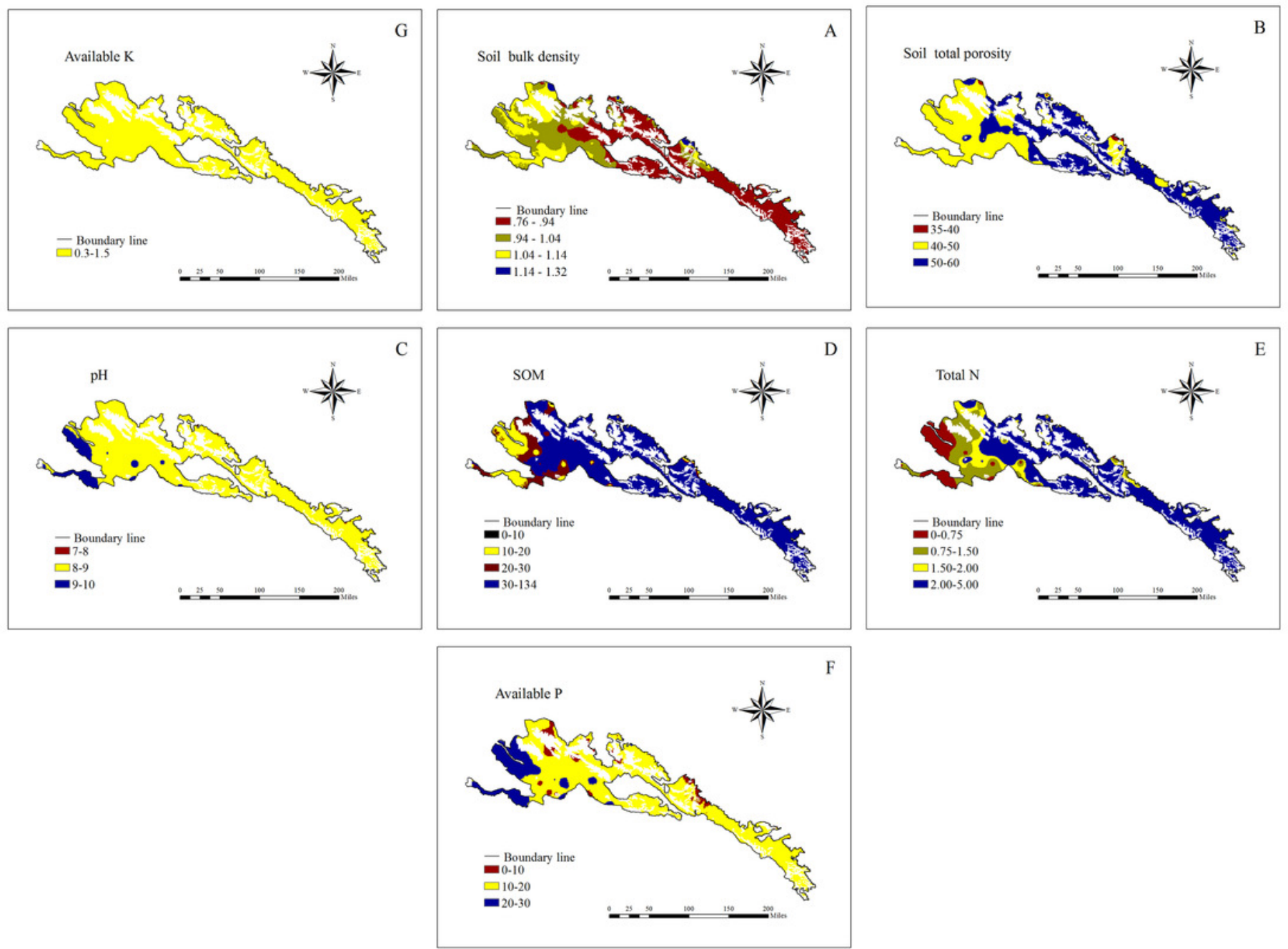
Figure 3

Fig.3 Spatial distribution of grassland soil comprehensive fertility index and limiting factors for grassland soil comprehensive fertility.
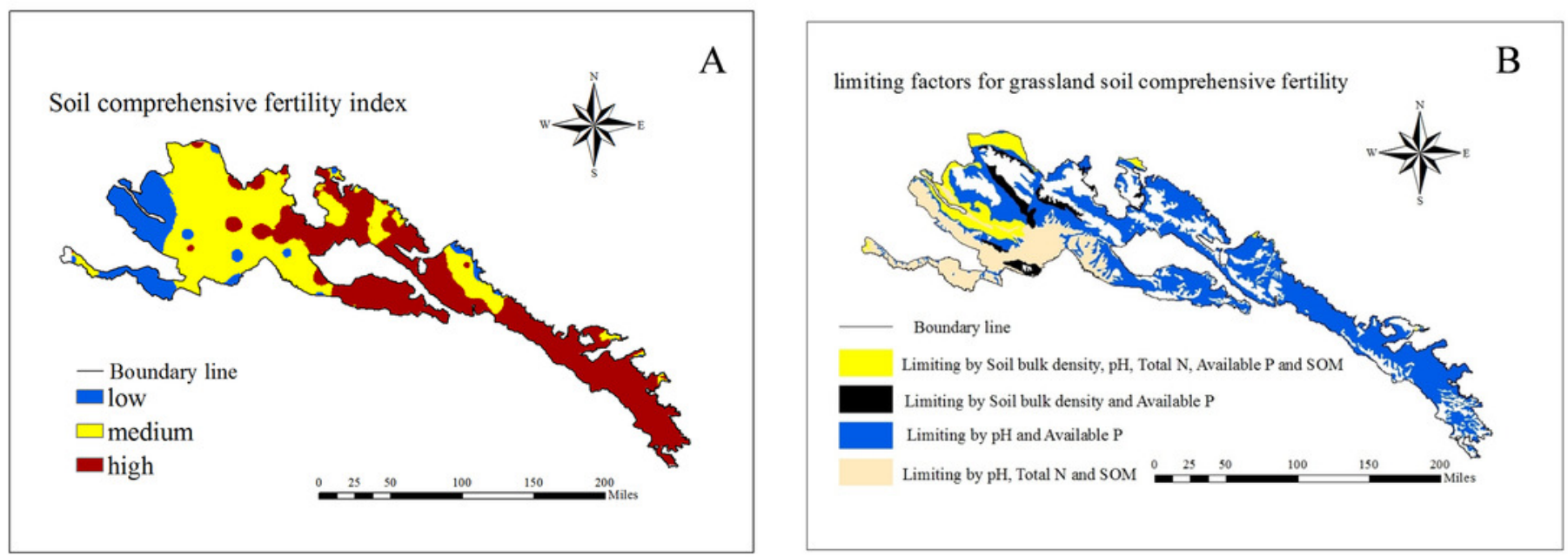